\title{
Bifid Tails in Two Indian Lizards
}

\author{
Raju Vyas
}

505, Krishnadeep Tower, Mission Road, Fatehgunj, Vadodara, Gujarat, India (razoovyas@hotmail.com)

A utotomy (tail loss, usually as a defense mechanism) is known to occur in many lizards (e.g., Arnold 1988). After breakage, tail stubs heal rapidly and regeneration begins (Bateman and Fleming 2009). In the process of regeneration, vertebrae do not regenerate and are replaced by a cartilaginous rod (Alibardi 2009). Two-tailed (bifid, two-pronged) and even poly-tailed (polyfid, more than two-pronged) lizards are not uncommon (e.g., Bellairs and Bryant 1985). This phenomenon usually occurs when a tail is only partially broken and does not detach completely, but is sufficiently broken to stimulate new tail growth. Herein, I present two examples of bifid tails, one in a House Gecko, Hemidactylus cf. brookii (Geckkonidae) and the other in a Sun Skink, Eutropis allapallensis (Mabuyidae), both from Gujarat State, India.

On 23 March 2016, I observed an adult gecko (Hemidactylus cf. brookii) with a bifid tail from the outskirts of Surat City. The anterior tail was normal, with enlarged, conical tubercles that were missing on the bifid sections, each of which was about $4 \mathrm{~cm}$ in length (Fig. 1). A week after the initial observation, the left prong was lost. Within two weeks, it grew back to about $1.5 \mathrm{~cm}$ in length (Fig. 1). On 7 April 2008, I had observed another adult gecko (Hemidactylus sp.) with a bifid tail at the Forest Guest House in Dangs (Fig. 2). On 28 March 2016, I found an Allapalli Grass Skink

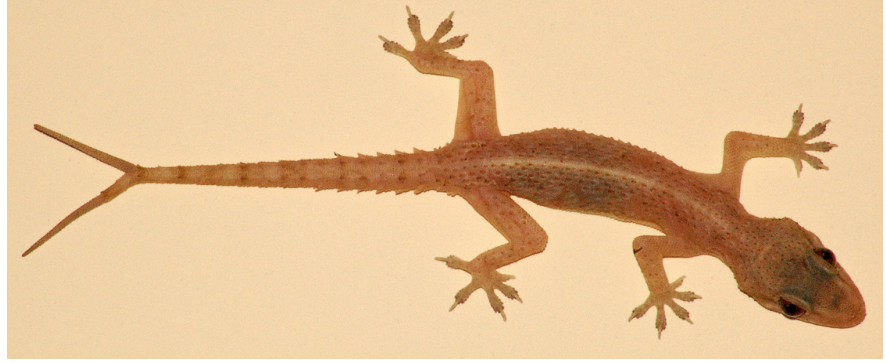

Fig. 2. An adult House Gecko (Hemidactylus sp.) with a bifid tail observed at the Forest Guest House, Dangs, Gujarat, India. Photograph (C) Viral Prjapati.

(Eutropis allapallensis; sometimes considered a synonym of $E$. macularia) with a bifid tail under leaf litter in the Sagai Forest Area, Shoolpaneswar Wildlife Sanctuary, Narmada District. The skink had a normal tail with a dorsal prong at about midtail (Fig. 3). To the best of my knowledge, these are the first records of bifid tails in these species.

\section{Acknowledgements}

I am very thankful to Mr. Kartick Upadhayay (Vadodara), Viral Prajapati, Dinkash Parmar, and Mr. Vasudev P. Limbachia for sharing information, providing photographs, and accompanying me in the field.
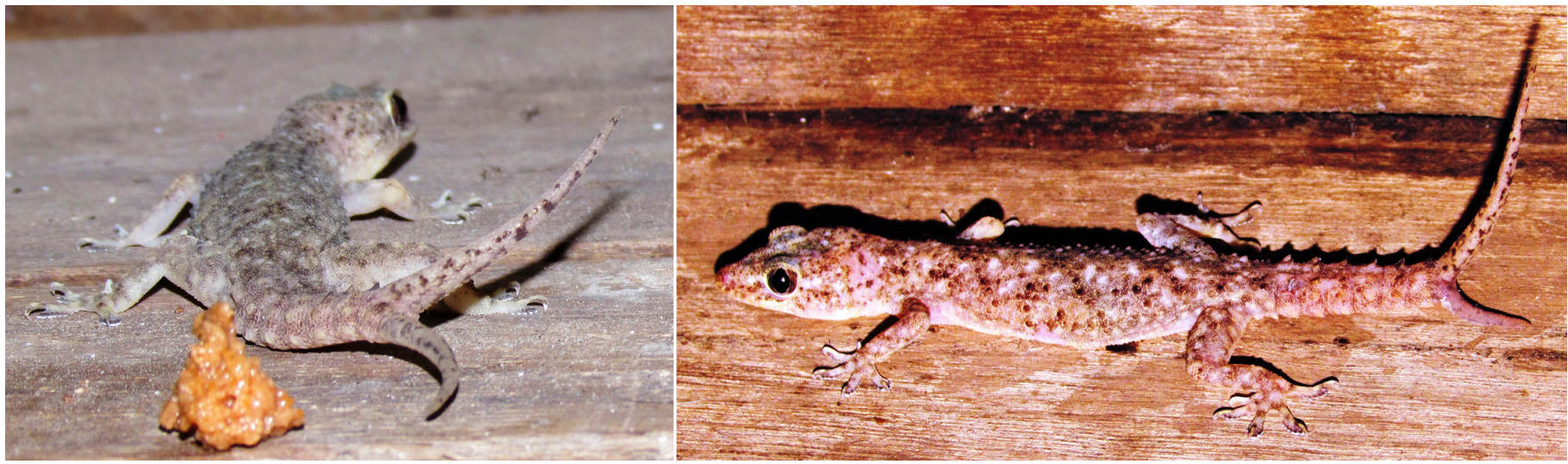

Fig. 1. An adult House Gecko (Hemidactylus cf. brookii; left) with a bifid tail observed in the vicinity of Surat City, Gujarat, India. The same adult gecko (right) with a bifid tail after the left prong was lost and subsequently regenerated. Photographs (C) Dinkash Parmar and Vasudev P. Limbachia. 


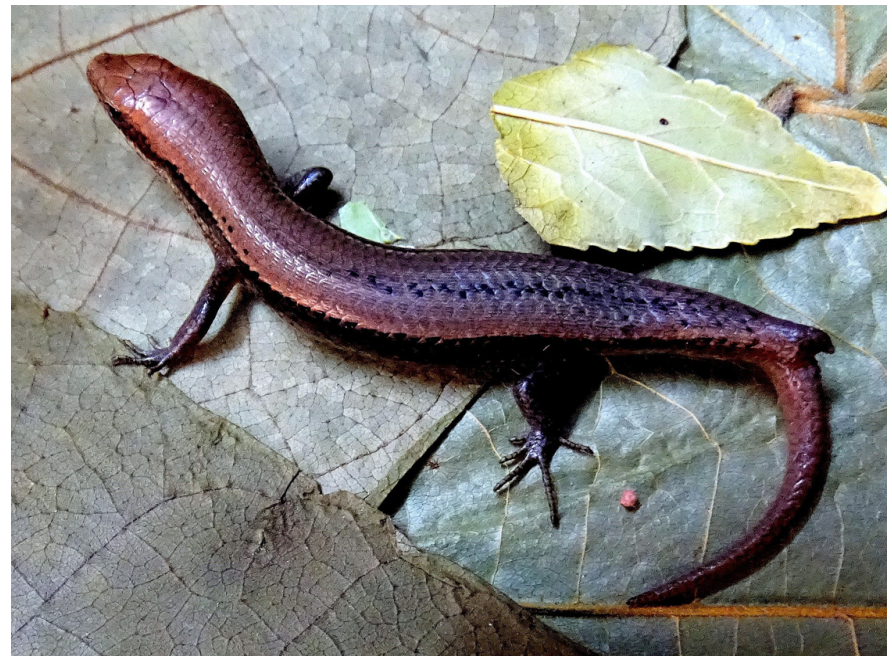

Fig. 3. An Allapalli Grass Skink (Eutropis allapallensis) with a bifid tail observed at the Sagai Forest Area of Shoolpaneswar Wildlife Sanctuary, Narmada District, Gujarat, India. Photograph (C) Raju Vyas.

\section{Literature Cited}

Alibardi, L. 2009. Morphological and Cellular Aspects of Tail and Limb Regeneration in Lizards: A Model System with Implications for Tissue Regeneration in Mammals. Springer-Verlag, Berlin, Germany.

Arnold, E.N. 1988. Caudal autotomy as a defense, pp. 235-273. In: C. Gans and R. Huey (eds.), Biology of the Reptilia. Volume 16. Ecology B: Defense and Life History. Alan R. Liss, New York.

Bateman, P.W. and P.A. Fleming. 2009. To cut a long tail short: A review of lizard caudal autotomy studies carried out over the last 20 years. Journal of Zoology 277: $1-14$.

Bellairs, A.D. and S.V. Bryant. 1985. Autotomy and regeneration in reptiles, pp. 303-410. In: C. Gans and F. Billett (eds.), Biology of the Reptilia. Volume 15. Development B. John Wiley \& Sons, New York. 